\title{
Methanoculleus chikugoensis sp. nov., a novel methanogenic archaeon isolated from paddy field soil in Japan, and DNA-DNA hybridization among Methanoculleus species
}

\author{
1 Laboratory of Soil \\ Microbiology, Kyushu \\ National Agricultural \\ Experiment Station, \\ Nishigoshi, Kumamoto \\ 861-1192, Japan \\ 2 Graduate School of \\ Agriculture and \\ Agricultural Life Sciences, \\ University of Tokyo, \\ Bunkyo-ku, Tokyo \\ 113-8657, Japan \\ 3 Department of \\ Environmental \\ Management, University of \\ Occupational and \\ Environmental Health, \\ Japan, Kitakyushu \\ 807-8555, Japan
}

\author{
Dayéri Dianou, ${ }^{1} \dagger$ Taro Miyaki, ${ }^{2} \ddagger$ Susumu Asakawa, ${ }^{1} \S$ Hiroyuki Morii, ${ }^{3}$ \\ Kazunari Nagaoka, ${ }^{1}$ Hiroshi Oyaizu ${ }^{2}$ and Satoshi Matsumoto ${ }^{2}$
}

\begin{abstract}
Author for correspondence: Susumu Asakawa. Tel: +8152789 5509. Fax: +81527894136. e-mail: asakawa@agr.nagoya-u.ac.jp
\end{abstract}

\begin{abstract}
A strictly anaerobic, irregularly coccoid, methanogenic archaeon, strain MG62 ${ }^{\top}$ ( = JCM $10825^{\top}=$ DSM $\left.13459^{\top}\right)$, was isolated from paddy field soil in Chikugo, Fukuoka, Japan. The cells stained Gram-negative, were 1.0-2.0 $\mu \mathrm{m}$ in diameter, were lysed by SDS and hypotonic solutions and were flagellated. Motility was not observed. The strain was able to use $\mathrm{H}_{2} / \mathrm{CO}_{2}, 2$-propanol/ $\mathrm{CO}_{2}$, formate, 2-butanol/ $/ \mathrm{CO}_{2}$ and cyclopentanol/ $\mathrm{CO}_{2}$ as substrates for methanogenesis, but did not utilize acetate, ethanol, methanol or methylamines. The optimum temperature and $\mathrm{pH}$ were $25-30{ }^{\circ} \mathrm{C}$ and 6.7-7.2. Analysis of lipid component parts (core lipids, phospholipid polar head groups and glycolipid sugar moieties) showed the characteristic pattern of members of the family Methanomicrobiaceae except for the absence of glucose as a glycolipid sugar moiety. The G+C content of the DNA was $62.2 \mathrm{~mol} \%$. Sequence analysis of the $16 S$ rDNA revealed that the strain belonged to the genus Methanoculleus. The strain had DNA-DNA hybridization values of less than $\mathbf{5 0} \%$ with type strains of Methanoculleus species. On the basis of phenotypic, genotypic and phylogenetic characteristics, the name Methanoculleus chikugoensis sp. nov. is proposed for strain MG62 $^{\top}$ ( = JCM 10825 ${ }^{\top}=$ DSM 13459'). The DNA hybridization study also revealed the close relationships of three species, Methanoculleus olentangyi, Methanoculleus bourgensis and Methanoculleus oldenburgensis, among Methanoculleus species.
\end{abstract}

Keywords: Methanoculleus chikugoensis sp. nov., methanogen, Archaea, paddy field soil

\section{INTRODUCTION}

Methane is one of the greenhouse gases, and paddy fields are reported to be an important source of atmospheric methane (Intergovernmental Panel on

\footnotetext{
† Present address: Laboratoire de Microbiologie Forestière, DPF/INERA, 03 BP 7047 Ouagadougou, Burkina Faso.

$\ddagger$ Present address: Institute of Genetic Ecology, Division of Environmental Information, Katahira, Aoba-ku, Sendai, Miyagi 980-8577, Japan.

$\S$ Present address: Soil Biology and Chemistry, Laboratory of Bioresource Functions, Department of Biological Mechanisms and Functions, Graduate School of Bioagricultural Sciences, Nagoya University, Chikusa, Nagoya 464-8601, Japan.

The DDBJ accession number for the $16 \mathrm{~S}$ rDNA sequence of strain $\mathrm{MG}^{\top}{ }^{\top}$ is AB038795.
}

Climate Change, 1995). Methane is produced by methanogenic archaea, and microbiological studies of methanogens are important for understanding methane emissions from paddy fields. In order to understand the ecology of the methanogenic archaea in paddy field soil, the characterization and identification of methanogenic isolates from paddy field soil are necessary. Almost all methanogens isolated so far from paddy field soil belong to the families Methanobacteriaceae and Methanosarcinaceae (Rajagopal et al., 1988; Conrad et al., 1989; Asakawa et al., 1993, 1995; Chen et al., 1993; Fetzer et al., 1993; Min et al., 1997; Großkopf et al., 1998; Joulian et al., 1998, 2000; Takeda, 1998; Adachi, 1999; Kubota \& Takeda, 1999). Kudo et al. (1997) demonstrated by analysis of $16 \mathrm{~S}$ rDNA clones amplified using PCR from 
DNA extracted from soil that Methanogenium-like methanogens existed in Japanese paddy soils, and a strain of Methanoculleus marisnigri has been isolated recently from a rice field in France by Joulian et al. (1998). These results suggest that members of the family Methanomicrobiaceae also exist in paddy field soil.

In this work, we isolated and characterized a methanogenic archaeon from a Japanese paddy field soil after enrichment with 2-propanol/ $\mathrm{CO}_{2}$. We selected 2propanol $/ \mathrm{CO}_{2}$ as a substrate and used a slightly saline medium $\left(6 \mathrm{~g} \mathrm{NaCl}^{-1}\right)$ in order to enrich methanogens belonging to the family Methanomicrobiaceae, since many species within this family are known to utilize secondary alcohols and they usually prefer slightly saline conditions $(0 \cdot 1 \mathrm{M} \mathrm{NaCl}$ or more) (Widdel et al., 1988; Boone et al., 1993). Phenotypic, genotypic and phylogenetic data show that the strain should be assigned as a novel species within the genus Methanoculleus, for which we propose the name Methanoculleus chikugoensis sp. nov. We also discuss genomic relationships among Methanoculleus species.

\section{METHODS}

Source of strain MG62 $^{\top}$ and reference strains. The sampling site was a paddy field plot (Gray Lowland Soil) with longterm application of rice straw compost at the Kyushu National Agricultural Experiment Station, Chikugo, Fukuoka, Japan (Asakawa et al., 1998). The sampling was performed on 29 August 1995 as described previously (Asakawa et al., 1993).

Methanoculleus marisnigri JR1 $1^{\mathrm{T}}$ ( = DSM $1498^{\mathrm{T}}$ ), Methanoculleus thermophilus CR-1 ${ }^{\mathrm{T}}$ (= DSM 2373 ${ }^{\mathrm{T}}$ ), Methanoculleus palmolei INSULZ ${ }^{\mathrm{T}}$ ( = DSM 4273 $)$, Methanoculleus oldenburgensis $\mathrm{CB}^{\mathrm{T}} \quad\left(=\mathrm{DSM} 6216^{\mathrm{T}}\right)$, Methanoculleus bourgensis $\mathrm{MS}^{\mathrm{T}}$ (=DSM $\left.3045^{\mathrm{T}}\right)$ and Methanoculleus olentangyi $\mathrm{RC} / \mathrm{ER}^{\mathrm{T}}$ (= DSM $2772^{\mathrm{T}}$ ) were obtained from the Deutsche Sammlung von Mikroorganismen und Zellkulturen (DSMZ), Braunschweig, Germany.

Media and growth conditions. The basal medium used for enrichment and isolation was a modification of LPBM (Zeikus, 1977) and contained $\left(1^{-1}\right.$ distilled water): $0.75 \mathrm{~g}$ $\mathrm{KH}_{2} \mathrm{PO}_{4}, 0.75 \mathrm{~g} \mathrm{~K}_{2} \mathrm{HPO}_{4}, 1.0 \mathrm{~g} \mathrm{NH}_{4} \mathrm{Cl}, 0.36 \mathrm{~g} \mathrm{MgCl}_{2} .6 \mathrm{H}_{2} \mathrm{O}$, $6.0 \mathrm{~g} \mathrm{NaCl}, 1 \cdot 0 \mathrm{~g}$ sodium acetate, $2 \cdot 0 \mathrm{~g}$ yeast extract (Difco), $2 \cdot 0 \mathrm{~g}$ Polypepton (Nihon Pharmaceutical), $10 \mathrm{ml}$ 2-propanol, $9 \mathrm{ml}$ trace mineral solution (Morii et al., 1983), $10 \mathrm{ml}$ vitamin solution (Balch et al., 1979), $0.5 \mathrm{ml} \mathrm{0.2 \%} \mathrm{(w/v)}$ resazurin, $0.5 \mathrm{~g}$ L-cysteine hydrochloride hydrate, $0.5 \mathrm{~g}$ $\mathrm{Na}_{2} \mathrm{~S}_{2} 9 \mathrm{H}_{2} \mathrm{O}$ and $4.8 \mathrm{~g} \mathrm{NaHCO}_{3}$. For roll tubes, $1.7 \%(\mathrm{w} / \mathrm{v})$ agar was added to the basal medium. The gas phase was $\mathrm{N}_{2} / \mathrm{CO}_{2}(4: 1,203 \mathrm{kPa})$ and the $\mathrm{pH}$ was $7 \cdot 0$. The medium used for cultivation of the isolate and reference strains was DSM 141 medium (DSMZ, 1993) supplemented with Polypepton (Nihon Pharmaceutical) instead of Trypticase. The headspace was filled with $\mathrm{H}_{2} / \mathrm{CO}_{2}(4: 1,203 \mathrm{kPa})$ at $\mathrm{pH} 7 \cdot 0$ or $\mathrm{N}_{2} / \mathrm{CO}_{2}(4: 1,203 \mathrm{kPa})$ when the substrates 2-propanol, sodium formate, 2-butanol and cyclopentanol were used. These substrates, cysteine and $\mathrm{Na}_{2} \mathrm{~S}$ were added from anoxic, sterile stock solutions. The media were prepared anoxically, basically according to Hungate technique (Hungate, 1969; Balch et al., 1979; Koga et al., 1987). Cultures were grown in $120 \mathrm{ml}$ serum bottles containing $10 \mathrm{ml}$ medium or in $18 \mathrm{~mm}$ (outside diameter) by $180 \mathrm{~mm}$ test tubes with $5 \mathrm{ml}$ medium.
Cells for lipid and DNA analyses were grown in 11 serum bottles containing $100 \mathrm{ml}$ medium at $27^{\circ} \mathrm{C}$ for strain MG62 $2^{\mathrm{T}}, 37^{\circ} \mathrm{C}$ for Methanoculleus bourgensis, Methanoculleus marisnigri, Methanoculleus olentangyi, Methanoculleus palmolei and Methanoculleus oldenburgensis and $55^{\circ} \mathrm{C}$ for Methanoculleus thermophilus.

The specific growth rate was calculated by monitoring the $\mathrm{OD}_{660}$. Media with different $\mathrm{pH}$ values were prepared by varying the ratio of the $\mathrm{H}_{2} / \mathrm{CO}_{2}$ mixture and the concentration of $\mathrm{NaHCO}_{3}$ or $\mathrm{Na}_{2} \mathrm{CO}_{3}$. The $\mathrm{H}_{2} / \mathrm{CO}_{2}$ mixture was repeatedly repressurized to $203 \mathrm{kPa}$ with the original ratio.

Methane production was determined by GC as described previously (Asakawa et al., 1995).

Enrichment and isolation. Enrichment was performed in 11 serum bottles sealed with butyl rubber stoppers and aluminium seals containing $100 \mathrm{ml}$ medium with 2propanol $/ \mathrm{CO}_{2}$ as growth substrate. A moist soil sample (about $20 \mathrm{~g}$ ) was inoculated into the medium and the bottle was incubated with shaking (120 r.p.m.) at $30^{\circ} \mathrm{C}$. About $80 \%$ of the culture was replaced fortnightly by fresh medium. After seven successive transfers, roll tubes were prepared. Many colonies formed within a few weeks, but they did not produce methane after inoculating into liquid medium. Some of the colonies that formed after 1 month showed fluorescence when observed with an epifluorescence microscope. Therefore, these colonies were inoculated into liquid medium and methane production was examined. Isolation of colonies from roll tubes was repeated and wellisolated colonies were picked and inoculated into the liquid medium. To test for purity, a culture was inoculated into the basal medium without $\mathrm{NaHCO}_{3}$ but containing $1 \%(\mathrm{w} / \mathrm{v})$ glucose and VL medium as described previously (Asakawa et al., 1993). The gas phase was $\mathrm{N}_{2}$. The preparations were incubated statically for $43 \mathrm{~d}$ at $30^{\circ} \mathrm{C}$. No growth was obtained and no contaminants were detected microscopically. The pure culture was designated strain MG62 ${ }^{\mathrm{T}}$.

Microscopy. Phase-contrast and epifluorescence microscopy were carried out by using a Nikon Optiphoto microscope and an Olympus VANOX microscope, respectively. Gram staining was carried out by the Hucker method. Cells for electron microscopy were collected from a late logarithmic culture at $10000 \mathrm{~g}$ for $2 \mathrm{~min}$. Resuspended cells were stained negatively with $2 \%$ phosphotungstic acid and observed with a Hitachi H-7000 electron microscope.

Lipid analysis. Cells were harvested at late exponential phase and stored at $-20^{\circ} \mathrm{C}$ until use. Extraction of total lipids and analysis of lipid component parts were conducted as described previously (Koga et al., 1993, 1998). The nomenclature for archaeal ether lipids proposed by Nishihara et al. (1987) is used in this paper.

G $+\mathbf{C}$ content of DNA and DNA-DNA hybridization. Cells of methanogenic strains harvested at late exponential phase were used for DNA isolation. DNA was isolated and purified according to the method of Sowers (1995). The $G+C$ content of the DNA was determined by HPLC (Tamaoka \& Komagata, 1984) with the equipment described previously (Asakawa et al., 1995).

DNA-DNA hybridization was performed according to the microtitration plate method (Ezaki et al., 1989; Sawada et al., 1995). Aliquots of $100 \mu \mathrm{l}$ denatured DNA solution $\left(3 \mu \mathrm{g} \mathrm{ml}^{-1}\right)$ in PBS-Mg buffer $(137 \mathrm{mM} \mathrm{NaCl}, 2.7 \mathrm{mM} \mathrm{KCl}$, $8 \mathrm{mM} \mathrm{Na} \mathrm{HPO}_{4}, 1.5 \mathrm{mM} \mathrm{KH_{2 }} \mathrm{PO}_{4}, 0.1 \mathrm{M} \mathrm{MgCl}_{2}$ ) were added to each well and the plate was kept at $30^{\circ} \mathrm{C}$ overnight for immobilization of DNA. The solution was then dis- 
carded and the plate was dried at $55^{\circ} \mathrm{C}$ for $24 \mathrm{~h}$. DNAs from methanogenic strains were labelled with digoxigenin (DIG; Roche Diagnostics) according to the protocol of the DIG DNA labelling and detection kit (Roche Diagnostics). Hybridization of DIG-labelled DNA to immobilized DNA was performed at $48{ }^{\circ} \mathrm{C}$ (optimal conditions for DNAs of $60 \% \mathrm{G}+\mathrm{C}$ content) with the hybridization mixture in $2 \times$ $\mathrm{SSC}(1 \times \mathrm{SSC}$ is $0 \cdot 15 \mathrm{M} \mathrm{NaCl}, 0.015 \mathrm{M}$ sodium citrate; $\mathrm{pH}$ not adjusted) with $50 \%$ formamide for $38 \mathrm{~h}$ according to the method described by Sawada et al. (1995) with the modifications that the amount of DIG-labelled DNA added into each well was $50 \mathrm{ng}$ and salmon sperm DNA was added to the hybridization mixture to a final concentration of $100 \mu \mathrm{g} \mathrm{ml} \mathrm{m}^{-1}$. Hybridized DNA was detected colorimetrically using $p$-nitrophenyl phosphate as a substrate following the method of Sawada et al. (1995) and the protocol of the kit (Roche Diagnostics). $A_{405}$ was measured with a model 550 Microplate Reader (Bio-Rad).

16S rDNA sequence analysis. 16S rDNA was amplified by PCR using primers $0025 \mathrm{eF}$ (5'-CTGGTTGATCCTGCCAG-3'; Escherichia coli positions 9-25) and 1525R (5'AAGGAGGTGATCCAGCC-3'; E. coli positions 15411525) (Achenbach \& Woese, 1995) according to the method described by Rainey et al. (1996) by using a GeneAmp PCR reagent kit with AmpliTaq DNA polymerase and a GeneAmp PCR 9700 System (Perkin Elmer). The PCR products were purified with Micro Spin S-400HR columns (Amersham Pharmacia Biotech) and sequenced with an ABI 373S automated sequencer (Applied Biosystems). Sequencing reactions were carried out using a PRISM Dye Terminator cycle sequencing ready reaction kit with AmpliTaq DNA polymerase FS (Applied Biosystems). Sequencing primers used were $0112 \mathrm{aR}$ (5'-CCACGTGTTACTSAGC-3'), 0348aF (5'-TCCAGGCCCTACGGG3'), 0690aR (5'-TTACAGGATTTCACT-3'), 0802aF (5'ATTAGATACCCGGGTA-3'), 1068F (5'-GCATGGCYGYCGTCAG-3'), 1100aR (5'-TGGGTCTCGCTCGTTG$\left.3^{\prime}\right), 1392 \mathrm{R}\left(5^{\prime}\right.$-ACGGGCGGTGTGTRC-3') and 1406F (5'TGYACACACCGCCCGT-3') (E. coli positions 128-112, 333-348, 704-690, 787-802, 1053-1068, 1115-1100, 14061392 and 1391-1406; Achenbach \& Woese, 1995) together with $0025 \mathrm{eF}$ and $1525 \mathrm{R}$ described above. Sequences were compared with the BLAST program (NCBI).

\section{RESULTS}

\section{Morphology}

Cells of strain MG62 ${ }^{\mathrm{T}}$ were irregularly coccoid and 1-2 $\mu \mathrm{m}$ in diameter (Fig. 1). The cells stained Gramnegative. Motility was not observed, but the cells were flagellated (Fig. 1b). SDS and hypotonic conditions lysed cells when the method described by Boone \& Whitman (1988) was used. This indicates that strain $\mathrm{MG}^{\mathrm{T}}{ }^{\mathrm{T}}$ has a proteinaceous cell wall.

Surface colonies on agar medium in roll tubes were $0.3-1.0 \mathrm{~mm}$ in diameter, round or ellipsoidal, entire, convex, smooth and yellow to ochre-yellow.

\section{Physiology}

Strain MG62 ${ }^{\mathrm{T}}$ grew on 2-propanol $(134 \mathrm{mM}) / \mathrm{CO}_{2}$ and was also able to utilize $\mathrm{H}_{2} / \mathrm{CO}_{2}$, formate $(40 \mathrm{mM})$, 2-butanol $(109 \mathrm{mM}) / \mathrm{CO}_{2}$ and cyclopentanol
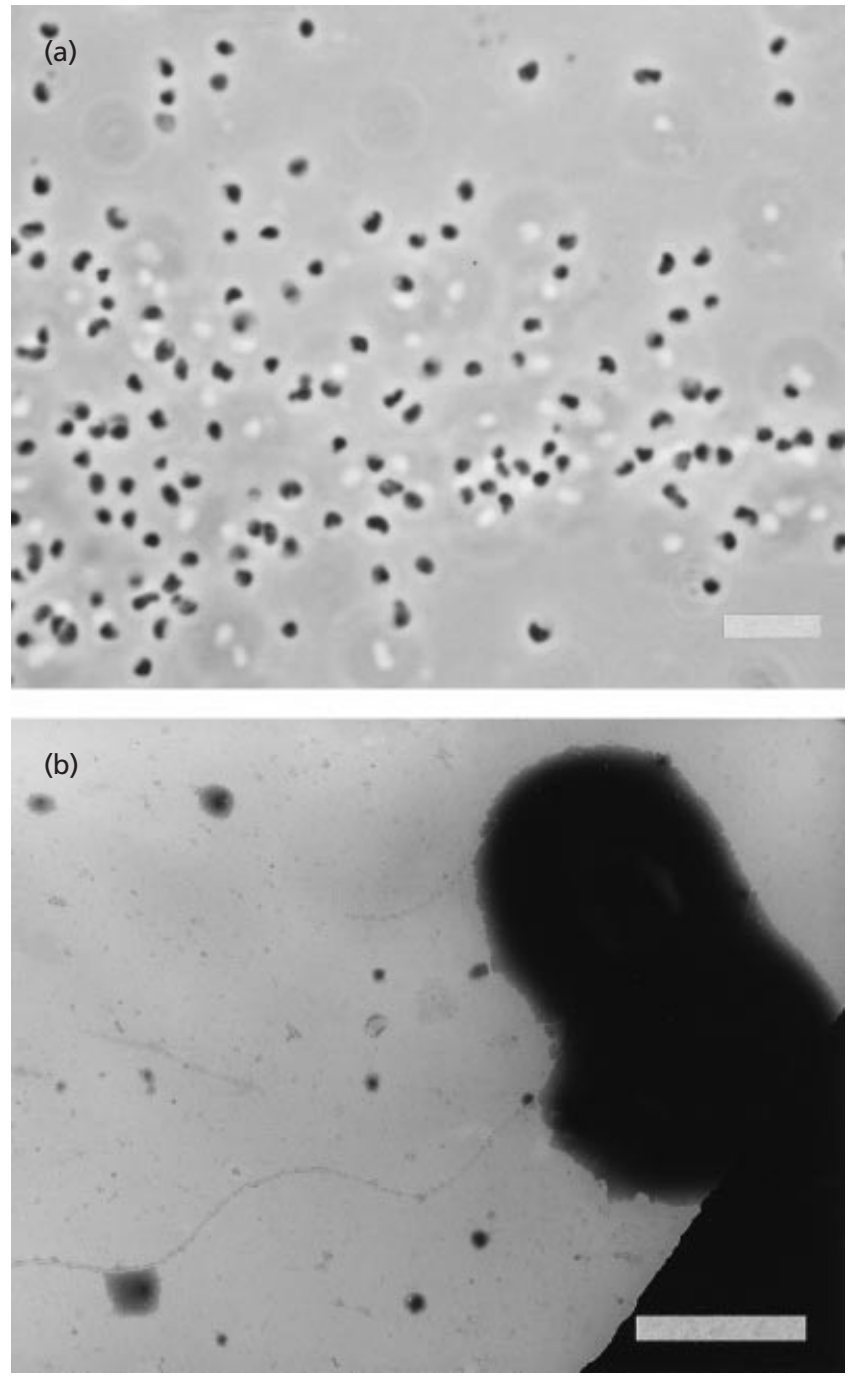

Fig. 1. (a) Phase-contrast micrograph of strain $M G 62^{\top}$. Bar, $5 \mu \mathrm{m}$. (b) Electron micrograph of negatively stained cells of strain $\mathrm{MG}^{\top} 2^{\top}$. Bar, $1 \mu \mathrm{m}$.

$(110 \mathrm{mM}) / \mathrm{CO}_{2}$ but not acetate $(80 \mathrm{mM})$, methanol $(250 \mathrm{mM})$, ethanol $(110 \mathrm{mM})$ or trimethylamine $(40 \mathrm{mM})$ as substrates for growth and methanogenesis. Growth on cyclopentanol $/ \mathrm{CO}_{2}$ was very slow. Yeast extract or Polypepton (Nihon Pharmaceutical), which is equivalent to Trypticase Peptone (BBL) and Casitone (Difco), and acetate were required for growth and methane production when growing on $\mathrm{H}_{2} / \mathrm{CO}_{2}$. The generation time was $46 \mathrm{~h}$ (specific growth rate $\left.0.015 \mathrm{~h}^{-1}\right)$ in $100 \mathrm{ml}$ DSM 141 medium in a 11 bottle with $\mathrm{H}_{2} / \mathrm{CO}_{2}(4: 1,203 \mathrm{kPa})$ at $\mathrm{pH} 7$ and $27^{\circ} \mathrm{C}$.

Fig. 2 shows the effect of temperature on growth and methane production. Strain MG62 ${ }^{\mathrm{T}}$ grew at $15-40{ }^{\circ} \mathrm{C}$. Growth was fastest at $25-30{ }^{\circ} \mathrm{C}$. Growth occurred between $\mathrm{pH} 6.7$ and 8.0 and was fastest at $\mathrm{pH}$ 6.7-7.2 (data not shown). Strain MG62 ${ }^{\mathrm{T}}$ grew well in the presence of $0-0.3 \mathrm{M} \mathrm{NaCl}$ and optimum growth was observed at $0 \cdot 1 \mathrm{M}$ (data not shown). 


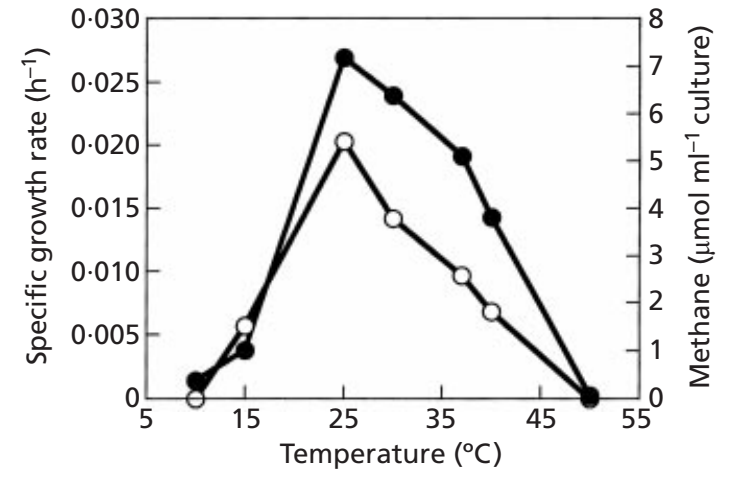

Fig. 2. Effect of temperature on growth and methane production of strain $\mathrm{MG}^{\top}$ cultivated in test tubes with $5 \mathrm{ml}$ DSM 141 medium on $\mathrm{H}_{2} / \mathrm{CO}_{2}$. Specific growth rate $(O)$ and methane production after $13 \mathrm{~d}$ of incubation $(\mathbf{0})$ are shown.

\section{Lipids}

Strain MG62 ${ }^{\mathrm{T}}$ contained archaeol and caldarchaeol as core lipids, galactose as glycolipid sugar and aminopentanetetrol and glycerol as phospholipid polar head groups. Glucose was not detected. Aminopentanetetrol was methylated.

\section{G + C content and DNA-DNA hybridization}

The $\mathrm{G}+\mathrm{C}$ content of DNA from strain $\mathrm{MG}^{\mathrm{T}}{ }^{\mathrm{T}}$ was $62 \cdot 2 \pm 1 \cdot 1 \%$ (mean \pm standard deviation, $n=3$ ).

Strain $\mathrm{MG}^{\mathrm{T}}$ exhibited DNA-DNA hybridization values of less than $50 \%$ with type strains of Methanoculleus species (Table 1). Methanoculleus olentangyi $\mathrm{RC} / \mathrm{ER}^{\mathrm{T}}$, Methanoculleus bourgensis $\mathrm{MS}^{\mathrm{T}}$ and Methanoculleus oldenburgensis $\mathrm{CB} 1^{\mathrm{T}}$ had values of $67-104 \%$ relatedness to each other.

\section{$16 \mathrm{~S}$ rDNA sequence analysis}

The 16S rDNA sequence of strain MG62 ${ }^{\mathrm{T}}$ (1430 bp) was compared with those available in DNA databases. The highest $16 \mathrm{~S}$ rDNA similarity, of $98.3 \%$, was obtained between strain MG62 ${ }^{\mathrm{T}}$ and Methanoculleus marisnigri strains $\mathrm{JR} 1^{\mathrm{T}}$ and CoCam (Joulian et al., 1998), followed by $97 \cdot 4 \%$ to Methanoculleus palmolei INSLUZ ${ }^{\mathrm{T}}$. Strain MG62 ${ }^{\mathrm{T}}$ showed similarities of $94 \cdot 5-$ $96 \cdot 3 \%$ to the other species of the genus Methanoculleus and at most $91.9 \%$ to genera within the families Methanomicrobiaceae, Methanoplanaceae and Methanocorpusculaceae.

\section{DISCUSSION}

The morphological and physiological features of strain $M G 62^{\mathrm{T}}$, such as cell form, flagellation, proteinaceous cell wall, substrate utilization and growth requirements, are similar to those found in members of the genera Methanogenium, Methanoculleus, Methanofollis and Methanocorpusculum (Romesser et al., 1979; Zellner et al., 1987, 1989, 1999; Maestrojuán et al., 1990). The lipid component composition of strain MG62 ${ }^{\mathrm{T}}$ exhibited the characteristic features, i.e. caldarchaeol as a core lipid, galactose as a glycolipid sugar, aminopentanetetrol and glycerol as phospholipid polar head groups, of the order Methanomicrobiales (Koga et al., 1998), which has been proposed to be separated from 'Methanosarcinales' by Boone et al. (1993). This suggests strongly that strain MG62 ${ }^{\mathrm{T}}$ belongs to the order Methanomicrobiales. The $\mathrm{G}+\mathrm{C}$ content of DNA of the genera Methanogenium and Methanocorpusculum is $47-52 \mathrm{~mol} \%$, while that of the genera Methanoculleus and Methanofollis ranges from 49 to $62 \mathrm{~mol} \%$ (Romesser et al., 1979; Rivard \& Smith, 1982; Corder et al., 1983; Ferguson \& Mah, 1983; Harris et al., 1984; Zabel et al., 1984, 1985; Ollivier et al., 1985, 1986; Zellner et al., 1987, 1989, 1990, 1998, 1999; Widdel et al., 1988; Xun et al., 1989; Zhao et al., 1989; Maestrojuán et al., 1990; Blotevogel et al., 1991). The DNA G + C content of strain MG62 ${ }^{\mathrm{T}}$ was $62 \mathrm{~mol} \%$, which indicates that the strain belongs to the genus Methanoculleus or Methanofollis. 16S rDNA sequence analysis revealed that strain MG62 should be assigned to the genus Methanoculleus and that it was most closely related to Methanoculleus marisnigri, although the similarity was no more than $98.3 \%$. The results of DNA-DNA hybridization

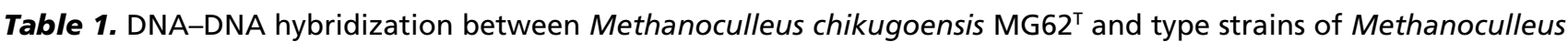
species

Values are percentage hybridization with DIG-labelled DNA from the species shown, and are means of four replicates.

\begin{tabular}{|c|c|c|c|c|c|c|c|}
\hline Strain & 1 & 2 & 3 & 4 & 5 & 6 & 7 \\
\hline 1. Methanoculleus chikugoensis $\mathrm{MG} 62^{\mathrm{T}}\left(=\mathrm{JCM} 10825^{\mathrm{T}}=\mathrm{DSM} 13459^{\mathrm{T}}\right)$ & 100 & 39 & 16 & 40 & 30 & 21 & 42 \\
\hline 2. Methanoculleus marisnigri $\mathrm{JR} 1^{\mathrm{T}}\left(=\mathrm{DSM} 1498^{\mathrm{T}}\right)$ & 47 & 100 & 12 & 26 & 34 & 23 & 40 \\
\hline 3. Methanoculleus thermophilus CR-1 ${ }^{\mathrm{T}}\left(=\mathrm{DSM} 2373^{\mathrm{T}}\right)$ & 16 & 22 & 100 & 21 & 35 & 20 & 31 \\
\hline 4. Methanoculleus palmolei INSLUZ $\left(=\right.$ DSM $\left.4273^{\mathrm{T}}\right)$ & 18 & 15 & 7 & 100 & 18 & 19 & 30 \\
\hline 5. Methanoculleus oldenburgensis $\mathrm{CB} 1^{\mathrm{T}}\left(=\mathrm{DSM} 6216^{\mathrm{T}}\right)$ & 25 & 16 & 6 & 25 & 100 & 77 & 104 \\
\hline 6. Methanoculleus bourgensis $\mathrm{MS}^{\mathrm{T}}\left(=\mathrm{DSM} 3045^{\mathrm{T}}\right)$ & 14 & 20 & 7 & 15 & 67 & 100 & 84 \\
\hline 7. Methanoculleus olentangyi $\mathrm{RC} / \mathrm{ER}^{\mathrm{T}}\left(=\mathrm{DSM} 2772^{\mathrm{T}}\right)$ & 19 & 23 & 15 & 19 & 76 & 80 & 100 \\
\hline
\end{tabular}


Table 2. Phenotypic characters of type strains of Methanoculleus species

Strains are listed as: 1, Methanoculleus chikugoensis $\mathrm{MG}^{\mathrm{T}}\left(=\mathrm{DSM} 13459^{\mathrm{T}}\right) ; 2$, Methanoculleus marisnigri $\mathrm{JR} 1^{\mathrm{T}}(=\mathrm{DSM}$

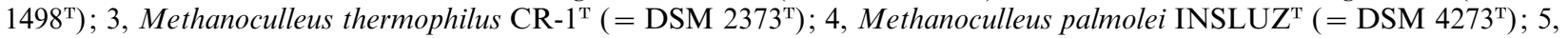
Methanoculleus oldenburgensis $\mathrm{CB} 1^{\mathrm{T}}\left(=\mathrm{DSM} 6216^{\mathrm{T}}\right) ; 6$, Methanoculleus bourgensis $\mathrm{MS} 2^{\mathrm{T}}\left(=\mathrm{DSM} 3045^{\mathrm{T}}\right) ; 7$, Methanoculleus $^{2}$ olentangyi RC/ER ${ }^{\mathrm{T}}$ ( = DSM 2772 ). Data were taken from this study (M. chikugoensis); Romesser et al. (1979) and Maestrojuán et al. (1990) (M. marisnigri); Rivard \& Smith (1982) (M. thermophilus); Zellner et al. (1998) (M. palmolei); Blotevogel et al. (1991) (M. oldenburgensis); Ollivier et al. (1986) and Maestrojuán et al. (1990) (M. bourgensis); and Corder et al. (1983) and Maestrojuán et al. (1990) (M. olentangyi). ND, Not determined.

\begin{tabular}{|c|c|c|c|c|c|c|c|}
\hline Characteristic & 1 & 2 & 3 & 4 & 5 & 6 & 7 \\
\hline Cell size $(\mu \mathrm{m})$ & $1-2$ & $1 \cdot 3$ & $1 \cdot 0-1 \cdot 3$ & $1 \cdot 25-2 \cdot 0$ & $1 \cdot 0$ & $1-2$ & $1 \cdot 0-1 \cdot 5$ \\
\hline Flagellation & + & + & + & - & - & - & - \\
\hline Substrates* & $\mathrm{H}, \mathrm{F}, \mathrm{P}, \mathrm{B}$ & $\mathrm{H}, \mathrm{F}, \mathrm{P}, \mathrm{B}$ & $\mathrm{H}, \mathrm{F}$ & $\mathrm{H}, \mathrm{F}, \mathrm{P}, \mathrm{B}$ & $\mathrm{H}, \mathrm{F}$ & $\mathrm{H}, \mathrm{F}, \mathrm{P}, \mathrm{B}$ & $\mathrm{H}, \mathrm{F}$ \\
\hline \multicolumn{8}{|c|}{ Optimum growth conditions: } \\
\hline Temperature $\left({ }^{\circ} \mathrm{C}\right)$ & $25-30$ & 40 & 55 & 40 & 45 & 37 & 37 \\
\hline $\mathrm{pH}$ & $6 \cdot 7-7 \cdot 2$ & $8 \cdot 0$ & $7 \cdot 0$ & $6 \cdot 9-7 \cdot 5$ & $8 \cdot 0$ & $6 \cdot 7$ & ND \\
\hline $\mathrm{NaCl}(\mathrm{M})$ & $0 \cdot 1$ & $0 \cdot 19$ & $0 \cdot 25$ & ND & $0 \cdot 04-0 \cdot 17$ & $0 \cdot 17$ & $0 \cdot 17$ \\
\hline $\mathrm{G}+\mathrm{C}$ content $(\mathrm{mol} \%) \dagger$ & $62 \cdot 2(\mathrm{Lc})$ & $61 \cdot 2(\mathrm{Bd})$ & $59(\mathrm{Bd})$ & $59 \cdot 5(\mathrm{Lc}), 59\left(T_{\mathrm{m}}\right)$ & $48 \cdot 6\left(T_{\mathrm{m}}\right)$ & $59(\mathrm{Bd})$ & $54 \cdot 4(\mathrm{Bd})$ \\
\hline
\end{tabular}

${ }^{*} \mathrm{H}, \mathrm{H}_{2} / \mathrm{CO}_{2}$; F, formate; P, 2-propanol $/ \mathrm{CO}_{2} ; \mathrm{B}, 2$-butanol $/ \mathrm{CO}_{2}$.

$\dagger$ Determined by: Lc, HPLC; Bd, buoyant density; $T_{\mathrm{m}}$, thermal denaturation.

experiments not only supported this assignment but also revealed that the genomic relatedness between strain $\mathrm{MG} 62^{\mathrm{T}}$ and the type strains of each of the Methanoculleus species was too low to identify strain $\mathrm{MG}^{\mathrm{T}}{ }^{\mathrm{T}}$ as belonging to one of the existing species of the genus Methanoculleus (Table 1). In addition, strain MG62 ${ }^{\mathrm{T}}$ exhibited distinctive features, i.e. optimum temperature and lipid component parts. The optimum temperature $\left(25-30^{\circ} \mathrm{C}\right)$ for growth of strain $\mathrm{MG}^{\mathrm{T}}$ is the lowest among the Methanoculleus species (Table 2). Methanoculleus marisnigri JR $1^{\mathrm{T}}$ was originally reported with a temperature optimum of $20-25^{\circ} \mathrm{C}$ (Romesser et al., 1979); however, this has been emended to $40{ }^{\circ} \mathrm{C}$ by Maestrojuán et al. (1990). Strain MG62 ${ }^{\mathrm{T}}$ did not contain glucose as a glycolipid sugar, which has been detected in all strains of the order Methanomicrobiales studied so far (Koga et al., 1998). On the basis of the phenotypic, genotypic and phylogenetic characteristics described above, we propose the name Methanoculleus chikugoensis sp. nov. for strain MG62 $^{\mathrm{T}}$.

DNA-DNA hybridization also revealed that Methanoculleus olentangyi $\mathrm{RC} / \mathrm{ER}^{\mathrm{T}}$, Methanoculleus bourgensis $\mathrm{MS}^{\mathrm{T}}$ and Methanoculleus oldenburgensis $\mathrm{CB} 1^{\mathrm{T}}$ were genomically closely related (Table 1 ). Xun et al. (1989) also reported a DNA hybridization value of $66 \%$ between Methanoculleus olentangyi $\mathrm{RC} / \mathrm{ER}^{\mathrm{T}}$ and Methanoculleus bourgensis MS2 ${ }^{\mathrm{T}}$. The 16S rRNA sequence similarity between Methanoculleus olentangyi $\mathrm{RC} / \mathrm{ER}^{\mathrm{T}}$ and Methanoculleus bourgensis $\mathrm{MS}^{\mathrm{T}}$ was $97.7 \%$ (the 16S rRNA sequence of Methanoculleus oldenburgensis $\mathrm{CB}^{\mathrm{T}}$ is not available), which also supports their close relationship. There seem to be few distinguishing phenotypic features of these three species (Table 2), with the single exception that the
$\mathrm{G}+\mathrm{C}$ content of Methanoculleus oldenburgensis $\mathrm{CB} 1^{\mathrm{T}}$ is $48.6 \mathrm{~mol} \%$. These results indicate that not only Methanoculleus olentangyi and Methanoculleus bourgensis, as reported already by Xun et al. (1989) and Boone et al. (1993), but also Methanoculleus oldenburgensis $\mathrm{CB}^{\mathrm{T}}$ are subjective synonyms. Since Methanoculleus olentangyi is the senior synonym, Methanoculleus olentangyi must be the name of the united species. However, as Methanoculleus bourgensis is the type species of the genus Methanoculleus, the genus would be lost. Therefore, we postpone the proposal of this synonymy until the genus Methanoculleus is conserved by an Opinion of the Judicial Commission. We will submit a Request for an Opinion on this matter later.

\section{Description of Methanoculleus chikugoensis sp. nov.}

Methanoculleus chikugoensis (chi.ku.go.en'sis. N. L. adj. chikugoensis of Chikugo, the city in Fukuoka, Japan, from where the strain was isolated).

Cells are irregularly coccoid, $1 \cdot 0-2 \cdot 0 \mu \mathrm{m}$ in diameter, with a proteinaceous cell wall, and flagellated. Strictly anaerobic. Cells grow on $\mathrm{H}_{2} / \mathrm{CO}_{2}$, formate, 2propanol $/ \mathrm{CO}_{2}$, 2-butanol $/ \mathrm{CO}_{2}$ and cyclopentanol/ $\mathrm{CO}_{2}$ as substrates for methanogenesis. Acetate, ethanol, methanol and methylamines are not utilized. The optimum temperature and $\mathrm{pH}$ for growth are $25-30{ }^{\circ} \mathrm{C}$ and 6.7-7.2. Cells contain archaeol and caldarchaeol as core lipids, aminopentanetetrol and glycerol as phospholipid polar head groups and galactose as glycolipid sugar, but glucose is absent. The type strain is $\operatorname{MG}^{\mathrm{T}}\left(=\mathrm{JCM} 10825^{\mathrm{T}}=\mathrm{DSM} 13459^{\mathrm{T}}\right)$, which was isolated from a paddy field soil in Chikugo, Fukuoka, Japan. 


\section{ACKNOWLEDGEMENTS}

This work was supported in part by the STA Fellowship Program from the Japan Science and Technology Cooperation. We thank K. Wakimoto, F. Tanaka and M. Nishida of the Kyushu National Agricultural Experiment Station for their help in taking the soil sample and Y. Koga of the University of Occupational and Environmental Health Japan and M. Akagawa-Matsushita of Minami-Kyushu University for their helpful advice.

\section{REFERENCES}

Achenbach, L. \& Woese, C. (1995). 16S and 23S rRNA-like primers. In Archaea: a Laboratory Manual. Methanogens, pp. 521-523. Edited by K. R. Sowers \& H. J. Schreier. Cold Spring Harbor, NY: Cold Spring Harbor Laboratory.

Adachi, K. (1999). Isolation of hydrogenotrophic methanogenic archaea from a subtropical paddy field. FEMS Microbiol Ecol 30, 77-85.

Asakawa, S., Morii, H., Akagawa-Matsushita, M., Koga, Y. \& Hayano, K. (1993). Characterization of Methanobrevibacter arboriphilus SA isolated from a paddy field soil and DNA-DNA hybridization among $M$. arboriphilus strains. Int $J$ Syst Bacteriol 43, 683-686.

Asakawa, S., Akagawa-Matsushita, M., Morii, H., Koga, Y. \& Hayano, K. (1995). Characterization of Methanosarcina mazeii TMA isolated from a paddy field soil. Curr Microbiol 31, 34-38.

Asakawa, S., Akagawa-Matsushita, M., Koga, Y. \& Hayano, K. (1998). Communities of methanogenic bacteria in paddy field soils with long-term application of organic matter. Soil Biol Biochem 30, 299-303.

Balch, W. E., Fox, G. E., Magrum, L. J., Woese, C. R. \& Wolfe, R. S. (1979). Methanogens: re-evaluation of a unique biological group. Microbiol Rev 43, 260-296.

Blotevogel, K.-H., Gahl-Janßen, R., Janssen, S., Fischer, U., Pilz, F., Auling, G., Macario, A. J. L. \& Tindall, B. J. (1991). Isolation and characterization of a novel mesophilic, fresh-water methanogen from river sediment, Methanoculleus oldenburgensis sp. nov. Arch Microbiol 157, 54-59.

Boone, D. R. \& Whitman, W. B. (1988). Proposal of minimal standards for describing new taxa of methanogenic bacteria. Int J Syst Bacteriol 38, 212-219.

Boone, D. R., Whitman, W. B. \& Rouvière, P. (1993). Diversity and taxonomy of methanogens. In Methanogenesis: Ecology, Physiology, Biochemistry \& Genetics, pp. 35-80. Edited by J. G. Ferry. New York: Chapman \& Hall.

Chen, M., Min, H. \& Qian, Z. (1993). Amount and dominant species of MPB in submerged paddy soil. Acta Pedol Sin 30, $432-437$.

Conrad, R., Bak, F., Seitz, H. J., Thebrath, B., Mayer, H. P. \& Schütz, H. (1989). Hydrogen turnover by psychrotrophic homoacetogenic and mesophilic methanogenic bacteria in anoxic paddy soil and lake sediment. FEMS Microbiol Ecol 62, 285-294.

Corder, R. E., Hook, L. A., Larkin, J. M. \& Frea, J. I. (1983). Isolation and characterization of two new methane-producing cocci: Methanogenium olentangyi, sp. nov., and Methanococcus deltae, sp. nov. Arch Microbiol 134, 28-32.

DSMZ (1993). Catalogue of Strains 1993. Braunschweig: Deutsche Sammlung von Mikroorganismen und Zellkulturen.

Ezaki, T., Hashimoto, Y. \& Yabuuchi, E. (1989). Fluorometric deoxyribonucleic acid-deoxyribonucleic acid hybridization in microdilution wells as an alternative to membrane filter hybridization in which radioisotopes are used to determine genetic relatedness among bacterial strains. Int J Syst Bacteriol 39, 224-229.

Ferguson, T. J. \& Mah, R. A. (1983). Isolation and characterization of an $\mathrm{H}_{2}$-oxidizing thermophilic methanogen. Appl Environ Microbiol 45, 265-274.

Fetzer, S., Bak, F. \& Conrad, R. (1993). Sensitivity of methanogenic bacteria from paddy field soil to oxygen and desiccation. FEMS Microbiol Ecol 12, 107-115.

Großkopf, R., Janssen, P. H. \& Liesack, W. (1998). Diversity and structure of the methanogenic community in anoxic rice paddy soil microcosms as examined by cultivation and direct $16 \mathrm{~S}$ rRNA gene sequence retrieval. Appl Environ Microbiol 64, 960-969.

Harris, J. E., Pinn, P. A. \& Davis, R. P. (1984). Isolation and characterization of a novel thermophilic, freshwater methanogen. Appl Environ Microbiol 48, 1123-1128.

Hungate, R. E. (1969). A roll tube method for cultivation of strict anaerobes. Methods Microbiol 3B, 117-132.

Intergovernmental Panel on Climate Change (1995). Climate Change 1994: Radioactive Forcing of Climate Change and an Evaluation of the IPCC IS92 Emission Scenarios. Edited by J. T. Houghton, L. G. Meira Filho, J. Bruce, H. Lee, B. A. Callander, E. Haites, N. Harris \& K. Maskell. Cambridge: Cambridge University Press.

Joulian, C., Ollivier, B., Patel, B. K. C. \& Roger, P. A. (1998). Phenotypic and phylogenetic characterization of dominant culturable methanogens isolated from ricefield soils. FEMS Microbiol Ecol 25, 135-145.

Joulian, C., Patel, B. K. C., Ollivier, B., Garcia, J.-L. \& Roger, P. A. (2000). Methanobacterium oryzae sp. nov., a novel methanogenic rod isolated from a Philippines ricefield. Int J Syst Evol Microbiol 50, 525-528.

Koga, Y., Morii, H. \& Nishihara, M. (1987). Methods for isolation and cultivation of methanogenic bacteria. Hakkokogaku 65, 419-430.

Koga, Y., Akagawa-Matsushita, M., Ohga, M. \& Nishihara, M. (1993). Taxonomic significance of the distribution of component parts of polar ether lipids in methanogens. Syst Appl Microbiol 16, 342-351.

Koga, Y., Morii, H., Akagawa-Matsushita, M. \& Ohga, M. (1998). Correlation of polar lipid composition with 16S rRNA phylogeny in methanogens. Further analysis of lipid component parts. Biosci Biotechnol Biochem 62, 230-236.

Kubota, A. \& Takeda, K. (1999). Syntrophic relationship between sulfate reducers and methanogens isolated from paddy field soil. Jpn J Soil Sci Plant Nutr 70, 164-170.

Kudo, Y., Nakajima, T., Miyaki, T. \& Oyaizu, H. (1997). Methanogen flora of paddy soils in Japan. FEMS Microbiol Ecol 22, 39-48.

Maestrojuán, G. M., Boone, D. R., Xun, L., Mah, R. A. \& Zhang, L. (1990). Transfer of Methanogenium bourgense, Methanogenium marisnigri, Methanogenium olentangyi, and Methanogenium thermophilicum to the genus Methanoculleus gen. nov., emendation of Methanoculleus marisnigri and Methanogenium, and description of new strains of Methanoculleus bourgense and Methanoculleus marisnigri. Int J Syst Bacteriol 40, 117-122.

Min, H., Zhao, Y. H., Chen, M. C. \& Zhao, Y. (1997). Methanogens in paddy rice soil. Nutr Cycl Agroecosyst 49, 163-169.

Morii, H., Nishihara, M. \& Koga, Y. (1983). Isolation, characterization and physiology of a new formate-assimilable 
methanogenic strain (A2) of Methanobrevibacter arboriphilus. Agric Biol Chem 47, 2781-2789.

Nishihara, M., Morii, H. \& Koga, Y. (1987). Structure determination of a quartet of novel tetraether lipids from Methanobacterium thermoautotrophicum. J Biochem 101, 1007-1015.

Ollivier, B. M., Mah, R. A., Garcia, J. L. \& Robinson, R. (1985). Isolation and characterization of Methanogenium aggregans $\mathrm{sp}$. nov. Int J Syst Bacteriol 35, 127-130.

Ollivier, B. M., Mah, R. A., Garcia, J. L. \& Boone, D. R. (1986). Isolation and characterization of Methanogenium bourgense sp. nov. Int J Syst Bacteriol 36, 297-301.

Rainey, F. A., Ward-Rainey, N., Kroppenstedt, R. M. \& Stackebrandt, E. (1996). The genus Nocardiopsis represents a phylogenetically coherent taxon and a distinct actinomycete lineage: proposal of Nocardiopsaceae fam. nov. Int J Syst Bacteriol 46, 1088-1092.

Rajagopal, B. S., Belay, N. \& Daniels, L. (1988). Isolation and characterization of methanogenic bacteria from rice paddies. FEMS Microbiol Ecol 53, 153-158.

Rivard, C. J. \& Smith, P. H. (1982). Isolation and characterization of a thermophilic marine methanogenic bacterium, Methanogenium thermophilicum sp. nov. Int J Syst Bacteriol 32, 430-436.

Romesser, J. A., Wolfe, R. S., Mayer, F., Spiess, E. \& WaltherMauruschat, A. (1979). Methanogenium, a new genus of marine methanogenic bacteria, and characterization of Methanogenium cariaci sp. nov. and Methanogenium marisnigri sp. nov. Arch Microbiol 121, 147-153.

Sawada, K., Nishida, K., Miyashita, K., Kimura, R. \& Hamada, R. (1995). Diversity among Streptomyces strains causing potato scab in Japan. Jpn J Soil Sci Plant Nutr 66, 599-608.

Sowers, K. R. (1995). Isolation of chromosomal and plasmid DNAs from methanogenic archaea. In Archaea: a Laboratory Manual. Methanogens, pp. 369-378. Edited by K. R. Sowers \& H. J. Schreier. Cold Spring Harbor, NY: Cold Spring Harbor Laboratory.

Takeda, K. (1998). Ecology and characterization of methanogens and methanotrophs in paddy soil. Microb Environ 13, 39-44.

Tamaoka, J. \& Komagata, K. (1984). Determination of DNA base composition by reversed-phase high-performance liquid chromatography. FEMS Microbiol Lett 25, 125-128.

Widdel, F., Rouvière, P. E. \& Wolfe, R. S. (1988). Classification of secondary alcohol-utilizing methanogens including a new thermophilic isolate. Arch Microbiol 150, 477-481.

Xun, L., Boone, D. R. \& Mah, R. A. (1989). Deoxyribonucleic acid hybridization study of Methanogenium and Methanocorpusculum species, emendation of the genus Methanocorpusculum, and transfer of Methanogenium aggregans to the genus Methanocorpusculum as Methanocorpusculum aggregans comb. nov. Int J Syst Bacteriol 39, 109-111.

Zabel, H.-P., König, H. \& Winter, J. (1984). Isolation and characterization of a new coccoid methanogen, Methanogenium tatii spec. nov. from a solfataric field on Mount Tatio. Arch Microbiol 137, 308-315.

Zabel, H. P., König, H. \& Winter, J. (1985). Emended description of Methanogenium thermophilicum, Rivard and Smith, and assignment of new isolates to this species. Syst Appl Microbiol 6, $72-78$

Zeikus, J. G. (1977). The biology of methanogenic bacteria. Bacteriol Rev 41, 514-541.

Zellner, G., Alten, C., Stackebrandt, E., Conway de Macario, E. \& Winter, J. (1987). Isolation and characterization of Methanocorpusculum parvum gen. nov., spec. nov., a new tungsten requiring, coccoid methanogen. Arch Microbiol 147, 13-20.

Zellner, G., Stackebrandt, E., Messner, P., Tindall, B. J., Conway de Macario, E., Kneifel, H., Sleytr, U. B. \& Winter, J. (1989). Methanocorpusculaceae fam. nov., represented by Methanocorpusculum parvum, Methanocorpusculum sinense spec. nov. and Methanocorpusculum bavaricum spec. nov. Arch Microbiol 151, 381-390.

Zellner, G., Sleytr, U. B., Messner, P., Kneifel, H. \& Winter, J. (1990). Methanogenium liminatans spec. nov., a new coccoid, mesophilic methanogen able to oxidize secondary alcohols. Arch Microbiol 153, 287-293.

Zellner, G., Messner, P., Winter, J. \& Stackebrandt, E. (1998). Methanoculleus palmolei sp. nov., an irregularly coccoid methanogen from an anaerobic digester treating wastewater of a palm oil plant in North-Sumatra, Indonesia. Int $J$ Syst Bacteriol 48, 1111-1117.

Zellner, G., Boone, D. R., Keswani, J., Whitman, W. B., Woese, C. R., Hagelstein, A., Tindall, B. J. \& Stackebrandt, E. (1999). Reclassification of Methanogenium tationis and Methanogenium liminatans as Methanofollis tationis gen. nov., comb. nov. and Methanofollis liminatans comb. nov. and description of a new strain of Methanofollis liminatans. Int J Syst Bacteriol 49, 247-255.

Zhao, Y., Boone, D. R., Mah, R. A., Boone, J. E. \& Xun, L. (1989). Isolation and characterization of Methanocorpusculum labreanum sp. nov. from the LaBrea Tar Pits. Int J Syst Bacteriol 39, 10-13. 